\title{
Deleterious effect of short-term gavage of an ethanol extract of cogon grass (Imperata cylindrica L.) roots on testis and epididymal sperm quality
}

\author{
Rini Widyastuti1,2(D), Sigit Prastowo ${ }^{3,4}$ (D), Sony H. Sumarsono ${ }^{5}$, Alkaustariyah Lubis ${ }^{6}$ (D), Tyagita Hartady ${ }^{7}$, \\ Mas R. A. A. Syamsunarno ${ }^{2,7(\mathbb{D})}$ and Jaqueline Sudiman ${ }^{8}$ (i)
}

\begin{abstract}
1. Laboratory of Animal Reproduction and Artificial Insemination, Department of Animal Production, Faculty of Animal Husbandry, Universitas Padjadjaran, Jl. Raya Bandung - Sumedang km. 21, West Java, Indonesia; 2. Central Laboratory, Universitas Padjadjaran, Jl. Raya Bandung - Sumedang km. 21, Jatinangor Sumedang, West Java, Indonesia

3. Department of Animal Science, Faculty of Agriculture, Universitas Sebelas Maret, Surakarta, Indonesia; 4 . Centre

for Biotechnology and Biodiversity Research and Development, Universitas Sebelas Maret, Surakarta, Indonesia; 5. Physiology, Developmental Biology and Biomedical Science Research Group, School of Life Science and Technology, Bandung Institute of Technology, Bandung, West Java, Indonesia; 6. Under Graduate Medical Study Program, Faculty of Medicine, Universitas Padjajaran, Jl. Raya Bandung - Sumedang km. 21, Jatinangor Sumedang, West Java, Indonesia; 7. Department of Biomedical Science, Faculty of Medicine, Universitas Padjadjaran, Jl. Raya Bandung - Sumedang km. 21, Jatinangor Sumedang, West Java, Indonesia; 8. Department of Obstetrics and Gynecology, Faculty of Medicine, Udayana University, Jl. PB. Sudirman, Denpasar, Bali, Indonesia.

Corresponding author: Sigit Prastowo, e-mail: prastowo@staff.uns.ac.id

Co-authors: RW: r.widyastuti@unpad.ac.id, SHS: sonyheru@sith.itb.ac.id, AL: alka.infinite7@gmail.com, TH: tyagita@unpad.ac.id, MRAAS: rizky@unpad.ac.id, JS: jaqueline@unud.ac.id Received: 06-02-2020, Accepted: 19-05-2020, Published online: 13-07-2020
\end{abstract}

doi: www.doi.org/10.14202/vetworld.2020.1311-1318 How to cite this article: Widyastuti R, Prastowo S, Sumarsono SH, Lubis A, Hartady T, Syamsunarno MRAA, Sudiman J (2020) Deleterious effect of short-term gavage of an ethanol extract of cogon grass (Imperata cylindrica L.) roots on testis and epididymal sperm quality, Veterinary World, 13(7): 1311-1318.

\section{Abstract}

Background and Aim: Cogon grass (Imperata cylindrica L.) (CGG) is a herbal medicine that could be developed into a male antifertility agent. The present study aims to determine the effect of an ethanol extract of CGG roots on mice testicular activity, reproductive hormone levels, and epididymal sperm quality.

Materials and Methods: This study was designed as completely randomized with three different doses, such as an ethanol extract of CGG roots at 0 (control), 90, and $115 \mathrm{mg} / \mathrm{kg}$ body weight. In total, 21 male DDY mice strain were treated with the CGG extract (by gavage) for 14 days, followed by an evaluation of reproductive organs, epididymal sperm quality, testis histology, histomorphometry, and reproductive hormone assays. All quantitative data were analyzed by analysis of variance, followed by Tukey's post hoc test at $\alpha=0.05$.

Results: The results showed that the administration of the CGG root ethanol extract disrupted the testis interstitial area and seminiferous tubules, resulting in decreased epididymal sperm quality as well as serum testosterone levels in a dosedependent pattern.

Conclusion: Oral administration of a CGG root ethanol extract induced testicular damage, decreased epididymal sperm quality, and impaired testosterone secretion.

Keywords: cogon grass root ethanol extract, epididymal sperm quality, male antifertility, reproductive hormones.

\section{Introduction}

Fertility control is an exciting public health issue concerned with controlling overpopulation. Several contraceptive methods have been adopted for fertility control, but most are synthetic or costly and have many side effects. Until now, the most widely developed contraceptive methods have been for women, but side effects cannot be avoided. In contrast, the development of male contraception remains limited. In principle, male contraception acts by blocking sperm from fertilizing the egg either by physical barriers or

Copyright: Widyastuti, et al. Open Access. This article is distributed under the terms of the Creative Commons Attribution 4.0 International License (http://creativecommons.org/licenses/by/4.0/), which permits unrestricted use, distribution, and reproduction in any medium, provided you give appropriate credit to the original author(s) and the source, provide a link to the Creative Commons license, and indicate if changes were made. The Creative Commons Public Domain Dedication waiver (http://creativecommons.org/ publicdomain/zero/1.0/) applies to the data made available in this article, unless otherwise stated. by inhibiting spermatogenesis $[1,2]$. One of the known methods is vasectomy, but it has a high failure rate and lacks complete reversibility [3]. Therefore, the development of an antifertility agent that is safe, effective, reversible, and rapid-acting without affecting androgen-dependent function should be emphasized. Herbs and medicinal plants have the potential to be used as antifertility agents. Many investigations have been carried out to validate the antifertility properties of plants, such as Bacolepis nervosa [4], Barleria prionitis [5], Actiniopteris radiata (SW.) L., and Selaginella bryopteris (L.) [6]. Moreover, one study reported on 48 plants that have antifertility potential [7], but many plants have not been investigated yet. Thus, safe, acceptable, reversible, easily administrable, inexpensive, effective, and nonsteroidal antifertility candidate from a plant extract are needed.

Cogon grass (Imperata cylindrica L.) (CGG) is a herbal medicine that has been traditionally used to 
treat urinary tract infections and intestinal disorders, such as dysentery and diarrhea, myalgia, night sweats, piles, common cold [8], astringency, arthritis [9], tonic, wounds, urodynia, febrifuge [10], cancer [11], parasites, and bacteria [12], as well as to treat hypertension [13]. Based on the phytochemical screening, CGG contains alkaloids, tannins, saponins, and phytosterols [14]. In vivo studies have suggested that saponins and alkaloids are pro-oxidant molecules that cause oxidative damage due to the effects of free radicals (FR) and reactive oxygen species (ROS) on sperm cells and sexual glands. The expression of ROS and FR may destroy testicular germ cells through membrane damage or macromolecular degradation, resulting in sperm abnormalities [15]. Flavonoids and alkaloids induce antispermatogenic activity by reducing the diameter of seminiferous tubules and the production of spermatocytes and spermatids. Furthermore, a reduction in the numbers of immature and mature Leydig cells occur and the number of degenerating cells increases significantly. An antiprogesterone effect was also observed that was attributed to the antifertility effect [16]. The previous studies have shown that short-term gavage of a CGG extract reduces sperm concentration [17], induces abnormal sperm morphology [18], and decreases folliculogenesis in female mice [19]. Thus, CGG has the potential to be developed as an herbal antifertility agent. However, the effects of a CGG extract on testis and sperm production have not been reported.

Hence, no study has investigated the effects of a CGG root ethanol extract on testicular histomorphology and reproductive hormones, which are strongly correlated with sperm quality. Changes in testosterone level and sperm quality are standard criteria used to characterize agents that may disrupt fertility [20]. Thus, we hypothesized that a CGG root ethanol extract could be a potential male antifertility herb. Therefore, this study aimed to determine the effect of short-term gavage of a CGG root ethanol extract on epididymal sperm quality, reproductive hormone levels, and testicular histology of male mice. This is the first preliminary study to investigate the antifertility potency of a CGG root ethanol extract.

\section{Materials and Methods}

\section{Ethical approval}

All animal procedures in this study were approved by the Health Research Ethics Committee of the Faculty of Medicine, Universitas Padjadjaran (number 1263/UN6.C10/PN/2017).

\section{Cogon grass extract}

The cogon grass was extracted by macerating the roots in $95 \%$ ethanol for $72 \mathrm{~h}$, followed by vacuum filtration and concentration under a vacuum evaporator. The concentrated extract was suspended in $0.5 \%$ carboxymethylcellulose, and dosages of 90 and $115 \mathrm{mg} / \mathrm{kg}$ body weight (BW) were based on a previous study [18].

\section{Experimental animals}

This study was performed at the Mouse Animal Laboratory, Faculty of Medicine and Central Laboratory, Universitas Padjadjaran. Twenty-one DDY strain mice (males; 8-12 weeks old) were obtained from PT. Biofarma (Bandung, Indonesia). The mice were housed under a 12/12 h light and dark cycle, with adequate air circulation, and had unrestricted access to water and standard feed (CV551, PT. Charoen Pokphan). The mice were assigned (in equal numbers) to three biological groups, such as a control, a group administered $0 \mathrm{mg} / \mathrm{kg}$ BW of the CGG ethanol extract (replaced with $0.5 \%$ carboxymethylcellulose) (Group A), $90 \mathrm{mg} / \mathrm{kg} \mathrm{BW}$ (Group B), and $115 \mathrm{mg} / \mathrm{kg}$ BW (Group C) daily per oral for 14 days.

\section{Reproductive organ evaluation}

The mice were anesthetized using isoflurane, followed by a BW measurement to evaluate the effect of the CGG root ethanol extract on reproductive organs. The mice were euthanized by cervical dislocation. The reproductive organs were isolated and removed from adherent tissues and blood, and the weights of the testis and accessory gland were recorded. The epididymis was removed to evaluate epididymal sperm quality. The ratio (index) between testis weight and BW was calculated, and the testicular tissue was stained for the histological analysis using hematoxylin and eosin (HE).

\section{Epididymal sperm quality evaluation}

\section{Sperm concentration}

Epididymal sperm concentration was counted using a hemocytometer. The epididymis was finely minced with anatomical scissors in $1 \mathrm{~mL}$ of physiological saline in a Petri dish, and sperm was released from the epididymal tissue at room temperature for $2 \mathrm{~min}$. Briefly, $1 \mu \mathrm{L}$ of the sperm suspension was diluted in $95 \mu \mathrm{L}$ of phosphate-buffered saline solution containing $10 \%$ formalin and $10 \%$ sucrose. Approximately $10 \mu \mathrm{L}$ of the diluted sperm suspension was transferred to a hemocytometer and allowed to stand for $5 \mathrm{~min}$. Sperm settled ware counted under a microscope at $200 \times$, and the sperm concentration was calculated $\left(\times 10^{6} / \mathrm{mL}\right)$.

\section{Sperm motility}

The percentage of motile sperm was determined in each sample by subjectively evaluating a drop of sperm suspension. Epididymal sperm was diluted with Tris buffer solution (3.63 g of Tris-hydroxymethyl aminomethane, $0.50 \mathrm{~g}$ glucose, $1.99 \mathrm{~g}$ of citric acid, and $100 \mathrm{~mL}$ of distilled water) on a prewarmed $\left(37^{\circ} \mathrm{C}\right)$ slide, and observed under a microscope at $400 \times$. Motility was scored from $0 \%$ to $100 \%$.

\section{Sperm viability}

Sperm viability was evaluated by eosin-nigrosin staining. The sperm was mixed with eosin-nigrosin (1:1) on an object-glass, smeared, dried at room temperature, and observed under a microscope at $400 \times$. In total, 200 sperm were evaluated; viable sperm were 
characterized by a pale color, while nonviable sperm was indicated by a red color on the sperm head. The proportion of viable sperm was expressed as a percentage $(\%)$ of the total number of observed sperm.

\section{Sperm abnormality}

Sperm morphology was observed under a microscope at $1000 \times$. A total of 200 sperm in samples from each animal were assessed for macrocephaly, microcephaly, pinhead, no-hook, curved midpiece, bent midpiece, coiled tail, looped tail, tailless, bent tail, and curved tail, which are all abnormal sperm. We only calculated the percentage of abnormal sperm as the proportion of total abnormal sperm to total observed sperm (\%).

\section{Testicular histology and histomorphometric evaluation}

The testis was fixed in $10 \%$ formaldehyde, embedded in paraffin, sliced to $5 \mu \mathrm{m}$, stained with $\mathrm{HE}$ and observed under a microscope. The sections were screened for histopathology and photographed. In total, 40 seminiferous tubules in each sample were examined for their diameter, width, and thickness of the epithelium. Moreover, the seminiferous tubules were scored to assess spermatogenesis using the Johnsen score, as described by Johnsen [21].

\section{Reproductive hormone assays}

Reproductive hormones were assayed using retro-orbital-collected blood samples incubated for $15 \mathrm{~min}$ at room temperature. The samples were centrifuged $1500 \times g$ for $10 \mathrm{~min}$, the serum was recovered, and the serum samples were stored at $-80^{\circ} \mathrm{C}$ until use. The concentrations of follicle-stimulating hormone (FSH), luteinizing hormone (LH), and testosterone were determined using the mouse FSH enzyme-linked immunosorbent assay (ELISA) kit (EM1035), the mouse LH ELISA kit (EM1188), and the mouse testosterone ELISA kit (EM1850), respectively. All ELISA kits were obtained from Fine Test Company (Hubei, China), and the assays were performed according to the manufacturer's protocol.

\section{Statistical analysis}

This study was a completely randomized design. Data were analyzed using analysis of variance, followed by Tukey's post hoc test at $\alpha=0.05$. All statistical analyses were performed using the $\mathrm{R}$ statistical language [22].

\section{Results}

To eliminate the effect of the CGG root ethanol extract on growth during the experiment, we evaluated the BW and reproductive organ weight of the mice in the three groups. As a result, the reproductive organ (testis, epididymis, and seminal vesicle) weights and BWs of the mice were not different after 14 days of treatment $(p>0.05)$. However, the testis and seminal vesicle indices in both treatment groups tended to decrease compared to the control. The only difference was in the ventral prostate index, where Group C was higher $(p<0.05)$ than the control and Group B (Table-1).

The control group assessment of testicular histology showed a compact and regular arrangement of spermatogonia in the seminiferous tubules, no lesions, and well-distributed Sertoli cells in the tubules surrounded by well-integrated smooth muscle. Leydig cells were distributed evenly in the interstitial space (Figure-1). In contrast, necrotic tubules marked by broken epithelial walls, inflammatory cells in and around the tubules, and fibrin deposits in the lumen were observed in the groups administered the CGG

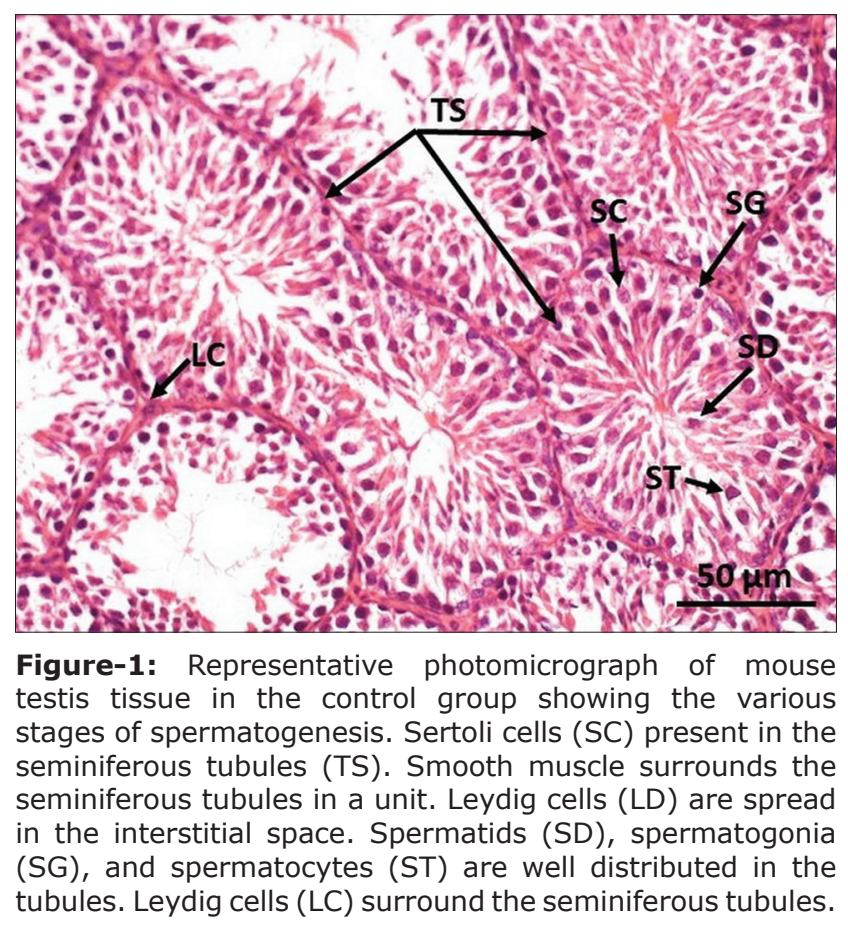

Table-1: Body weight and reproductive organ index of mice.

\begin{tabular}{|c|c|c|c|}
\hline \multirow[t]{2}{*}{ Parameter } & \multicolumn{3}{|c|}{ Group } \\
\hline & Control & 90 mg/kg & $115 \mathrm{mg} / \mathrm{kg}$ \\
\hline \multicolumn{4}{|l|}{ Body weight (g) } \\
\hline Initial & $41.18 \pm 5.48$ & $40.58 \pm 2.39$ & $40.96 \pm 4.85$ \\
\hline Final & $41.58 \pm 6.10$ & $40.36 \pm 3.59$ & $41.43 \pm 5.46$ \\
\hline \multicolumn{4}{|c|}{ Reproductive organ index } \\
\hline Testis & $0.65 \pm 0.14$ & $0.59 \pm 0.12$ & $0.58 \pm 0.09$ \\
\hline Epididymis & $0.27 \pm 0.07$ & $0.24 \pm 0.03$ & $0.26 \pm 0.05$ \\
\hline Seminal vesicle & $0.19 \pm 0.08$ & $0.15 \pm 0.14$ & $0.08 \pm 0.03$ \\
\hline Ventral prostate & $0.32 \pm 0.09^{a}$ & $0.31 \pm 0.14^{a, b}$ & $0.51 \pm 0.22^{b}$ \\
\hline
\end{tabular}

$a, b$ Values followed by different superscript in the same row showed significant difference $(p<0.05)$ 
root ethanol extract. Necrotic Leydig cells were also observed in the interstitial space. The severity of the lesions increased with the increase in the concentration of the CGG root ethanol extract administered (Group B in Figure-2 and Group C in Figure-3).

No differences $(\mathrm{p}>0.05)$ were detected in testis diameter or testis area among the groups (Table-2), but a difference was found in epithelial cell height $(p<0.05)$. The histological data generally showed a decreasing trend in the treatment groups compared to the control. The control group had the largest testis diameter and testis area compared to the treatment (B and C) groups, and this also applied to the thickness of the epithelium, in which the control was thicker than the treatment groups.

Sperm concentration, motility, and viability of Groups B and C were lower $(p<0.05)$ than the control. Moreover, we also detected a greater number of abnormal sperm in the groups that received the CGG root ethanol extract (Table-3).

The CGG root ethanol extract significantly $(p<0.05)$ reduced the testosterone level by $44 \%$ (Group B) and 62\% (Group C) compared with the control group. FSH and LH levels were not significantly different $(p>0.05)$ between the treatment groups and the control (Figure-4).

\section{Discussion}

The testis is the main reproductive organ in males, and its accessory structures are responsible for maintaining sperm production. Several herbs alter testicular function, which leads to changes in sperm quantity and quality by interfering with spermatogenesis. Our results show that oral administration of the CGG root ethanol extract for 14 days to adult mice

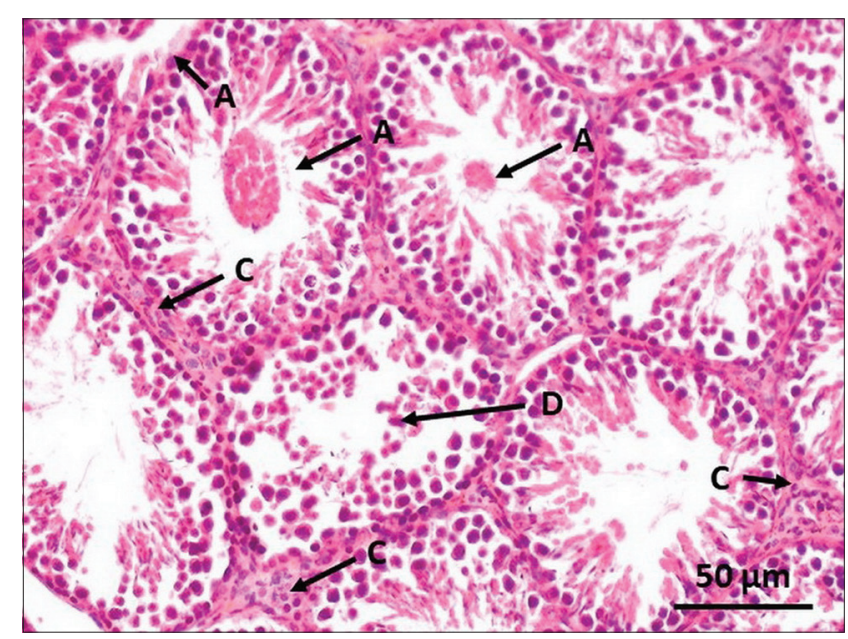

Figure-2: Representative photomicrograph of a mouse testis tissue from Group B (treated with $90 \mathrm{mg} / \mathrm{kg}$ body weight cogon grass [Imperata cylindrica L.] root ethanol extract) shows injured tubule marked by a broken epithelial wall (A). Degenerated tubules marked by the fibrin and hyaline presentation in the lumen $(B)$. The interstitial space was filled with necrotic Leydig cells and inflammatory cells (C). Luminal diameter decreased and the germ cells arrested at the early stage of spermatogenesis (primary and secondary spermatocytes) (D). had no effect on growth between the groups (Table-1), indicating that the CGG root ethanol extract is nontoxic and was consumed safely.

The testes, epididymis, seminal vesicles, and ventral prostate are androgen-dependent organs, relying on testosterone for their function and growth [23]. Therefore, the decrease in the testis-BW ratio (index) and seminal vesicle BW ratio observed in this study may indicate decreased androgen bioavailability. Moreover, the decrease in the testis-BW ratio may result in testis atrophy, a reduction in the size of the seminiferous tubules, inhibited steroid synthesis in Leydig cells, and altered testicular structure and function [24].

The histopathological findings showed a significant change in testis structure between the treatment groups and the control group, which exerted an adverse effect on spermatogenesis. According to the histological observations, administering the CGG root ethanol extract injured the seminiferous tubules (Figures-2 and 3). A previous study showed that vacuolation of Sertoli cells is the most common response to injury [25]. Once the cells degenerate, their full function is inhibited. Germ cells will be unable to be transferred from the base to the luminal tubule. Damaged Sertoli cells are unable to synthesize essential molecules and substrates for germ cell metabolism, which impairs spermatogenesis.

Interstitial hyperplasia was enhanced and related to increasing the CGG root dose. This was described in our results (Figures-2 and 3) as enhancement of the interstitial space filled with inflammatory cells, debris, and eosinophilic granular cells. A previous study observed hyperplasia of interstitial cells

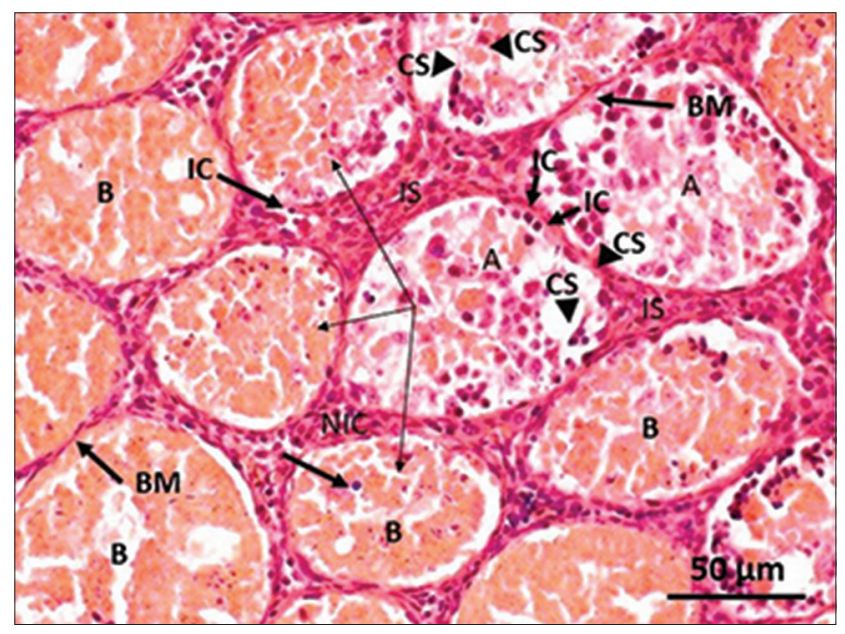

Figure-3: Representative photomicrograph of a rat testis tissue from Group C (treated with $115 \mathrm{mg} / \mathrm{kg}$ body weight cogon grass [Imperata cylindrica L.] root ethanol extract) shows severe hemorrhage of the seminiferous tubules and tubule degeneration (A); necrotic tubule (B) marked by blood infiltration filled the luminal tubule, intracellular necrosis (light arrow) and thinned basal membrane. Inflammatory cells present in the tubules and interstitial space (IC). Debris thickens in the interstitial space (IS). Some tubules are degenerating/cloudy swelling (CS) (arrowhead) and necrotic interstitial cells (NIC). 
Table-2: Mice testis histomorphometry after the cogon grass (Imperata cylindrica L.) treatment.

\begin{tabular}{lccc}
\hline Parameter & \multicolumn{3}{c}{ Group } \\
\cline { 2 - 4 } & Control & $\mathbf{9 0} \mathbf{~ m g / k g}$ & $\mathbf{1 1 5} \mathbf{~ m g / k g}$ \\
\hline Tubular testis diameter $(\mu \mathrm{m})$ & $1682.42 \pm 108.21$ & $1624.51 \pm 131.61$ & $1500.09 \pm 103.07$ \\
Area $(\mathrm{mm})$ & $2253.89 \pm 0.30$ & $2129.07 \pm 0.31$ & $1587.41 \pm 0.31$ \\
Epithelia height $(\mu \mathrm{m})$ & $423.25^{\mathrm{a}} \pm 88.19$ & $419.79^{\mathrm{a}} \pm 90.42$ & $307.53^{\mathrm{b}} \pm 90.13$ \\
\hline
\end{tabular}

$a, b$ Values followed by different superscript in the same row showed significant difference $(p<0.05)$

Table-3: Mice epididymal sperm quality after the cogon grass (Imperata cylindrica L.) treatment.

\begin{tabular}{lcrr}
\hline Sperm quality & \multicolumn{3}{c}{ Group } \\
\cline { 2 - 4 } & Control & $\mathbf{9 0 ~} \mathbf{~ m g / k g}$ & $\mathbf{1 1 5} \mathbf{~ m g / k g}$ \\
\hline Sperm concentration $\left(\times 10^{6} / \mathrm{mL}\right)$ & $14.45 \pm 1.86^{\mathrm{a}}$ & $11.12 \pm 2.71^{\mathrm{b}}$ & $6.89 \pm 1.03^{\mathrm{c}}$ \\
Sperm motility $(\%)$ & $62.29 \pm 5.07^{\mathrm{a}}$ & $49.00 \pm 5.63^{\mathrm{b}}$ & $26.21 \pm 5.37^{\mathrm{c}}$ \\
Sperm viability $(\%)$ & $66.86 \pm 4.42^{\mathrm{a}}$ & $58.00 \pm 3.11^{\mathrm{b}}$ & $33.93 \pm 4.39^{\mathrm{c}}$ \\
Abnormal sperm $(\%)$ & $37.29 \pm 0.81^{\mathrm{a}}$ & $55.36 \pm 4.92^{\mathrm{b}}$ & $64.86 \pm 2.41^{\mathrm{c}}$ \\
\hline
\end{tabular}

$a, b, c$ Values followed by different superscript in the same row showed significant difference $(p<0.05)$

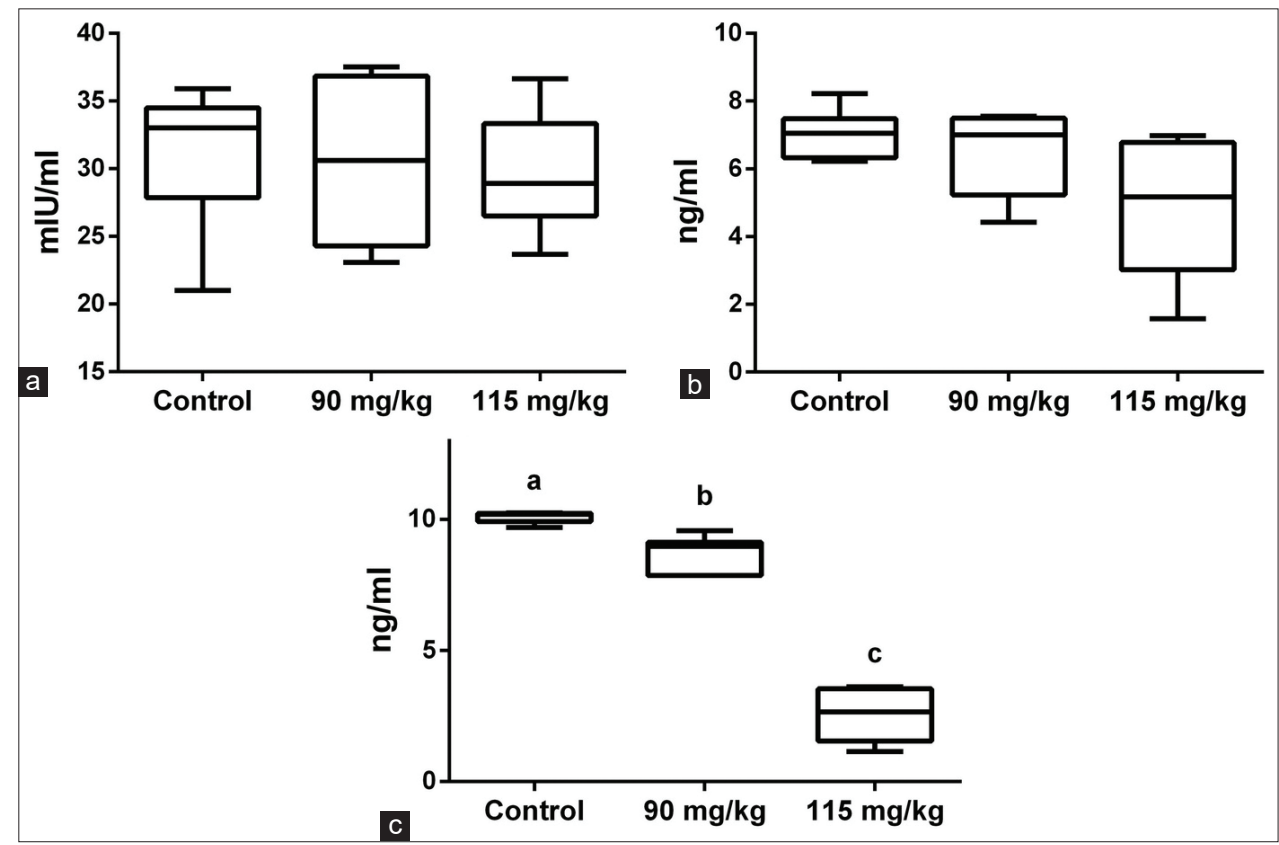

Figure-4: Mice reproductive hormone levels (a) FSH, (b) $\mathrm{LH}$, and (c) testosterone after the cogon grass (Imperata cylindrica L.) treatment. Data are mean \pm standard deviation, and values with different letters differ significantly $(p<0.05)$ by group. $\mathrm{FSH}=$ Follicle-stimulating hormone, $\mathrm{LH}=$ Luteinizing hormone.

(Leydig cells) marked by diffuse and consisting of an increased number of interstitial cells, which were not compressed to adjacent seminiferous tubules [26]. Diffuse hyperplasia is a physiological response to a hormone imbalance.

Meiosis and sperm production occurs in the seminiferous tubules [27]. In this study, the morphometric evaluation showed a decrease in area and a decrease in the spermatogenic cell layers (epithelial height) in a dose-dependent manner (Table-2). These decrease disrupted spermatogenesis, particularly by disturbing germinal cell mitosis, which resulted in a reduced sperm count (Table-3). Furthermore, the disturbance within the seminiferous tubules triggered the arrest of sperm maturation at different stages of development and an increase in abnormal primary sperm morphology, such as tapered heads, macro and microcephaly, amorphous heads, double heads, and knobbed acrosomal defects [28].

FSH, LH, and testosterone are sex hormones regulated by the hypothalamic-pituitary-testicular axis. FSH and LH are secreted by the anterior pituitary and bind to receptors in gonadal and non-gonadal organs. Testes contain Leydig cells that produce androgens to control FSH and LH production through inhibitory action at both the central nervous system and pituitary levels. The negative feedback effect of androgens decreases the responsiveness of the pituitary to gonadotropin-releasing hormone, thereby resulting in a decrease in LH pulse amplitude and a fall in plasma LH level. Testosterone regulates spermatogenesis by phosphorylating the cAMP response element-binding 
protein, and the increase in testosterone has a pivotal role in sperm quality and quantity [29]. In our study, the testosterone levels of the treated animals decreased significantly compared to the control, which was followed by a tendency for a decrease in FSH and LH levels, although it was not a significant difference (Figure-4). The decrease in testosterone may have disrupted Leydig cell function (as shown in Figures-2 and 3); however, the disruption did not induce the decrease in FSH and LH though a negative feedback mechanism. The CGG ethanol extract may act locally at the testis, and the damage may have only occurred in the tubular epithelium. The local action of CGG could be to disrupt the spermatogenesis cycle without permanently damaging the tubules [30]. Then, the epithelium would be able to regenerate during the next spermatogenic cycle within months or years. This is because the spermatogonial stem cells split infrequently and is less sensitive to toxicity compared to spermatogonia during the proliferative and developmental stages; thus, terminating the toxic compound may regenerate testis through surviving spermatogonial stem cells during seminiferous epithelial reconstruction [31].

The decrease in testosterone levels may have diminished the secretion of important substances from epididymis luminal fluid. This fluid contains ions, such as glutathione-independent prostaglandin D2 synthase, glutathione peroxidase, $\beta$-defensin, lipocalins, and cystatin-related epididymal-spermatogenic [32] that support sperm maturation and contribute directly to control cAMP concentration, which activates protein phosphorylation and sperm motility [33]. Therefore, the disturbance in the epididymis limited the energy and nutrients for sperm during maturation, resulting in diminished sperm motility (Table-3). Furthermore, the epididymal disturbance induced defects in secondary sperm morphology characterized by midpiece and tail damage or abnormal secondary sperm morphology [34]. This agrees with a previous study showing that short-term gavage of a CGG root ethanol extract induces abnormal secondary sperm morphology [18].

LH stimulates testosterone production from Leydig cells, and FSH stimulates Sertoli cells in synergy with testosterone to produce the regulatory molecules and nutrients needed to maintain spermatogenesis. FSH is correlated with Sertoli cell proliferation and testis size. In postpubertal testis, FSH, and testosterone evoke Sertoli cells signals to propagate germ cell maturation and provide antiapoptotic survival factors to regulate adhesion complexes between the germ cells and Sertoli cells. The antiapoptotic factors prevent apoptosis in spermatogonia and spermatocytes; thus, affecting sperm viability [29]. Based on our findings (Table-3), sperm viability decreased significantly in all treated animals compared to the control. The decrease in sperm viability may be related to the toxic properties of the CGG root ethanol extract. As reported in an earlier study, toxicity shrinks sperm cells and affects cell membrane permeability [35]. This disruption in membrane permeability affects sperm viability by interrupting membrane transport processes as well as the absorption of nutrients by sperm.

A phytochemical analysis of the CGG root ethanol extract revealed the presence of large chemical groups, including alkaloids, tannins, saponins, and phytosterols [14]. A previous study reported that the administration of alkaloids and triterpenoids has a negative effect on fertility [36], as they can inhibit spermatogenesis [37] and alter the morphology and histology of testes [38]. These results are comparable with a study that administered Cissampelos capensis rhizomes, which caused a dose-dependent increase in sperm intrinsic superoxide production leading to sperm capacitation and DNA fragmentation [39]. A similar study using withanolide-A also reported a decrease in the testosterone levels in rats, which reduced fertility and inhibited spermatogenesis [40]. Another study that administered Catharanthus roseus (L.) reported reduced reproductive organ weights and deceased sperm counts and serum testosterone levels in high-dose treated animals [41].

The CGG root ethanol extract had a significant effect on testosterone levels and adversely affected the semen parameters and testicular histology. These results suggest that the deleterious effects of CGG may mainly be on seminiferous tubules without affecting hypothalamic-pituitary function. Further investigations are needed to test the effect of the CGG root ethanol extract on mating rate and the reversibility of testicular damage and sperm quality after long-term administration to justify that it is a good candidate as a male antifertility agent. In addition, further research about the appropriate dose and potential for toxicity is required to fully evaluate the effects of the CGG root ethanol extract.

\section{Conclusion}

This study revealed that administering an ethanol extract of CGG roots to male mice induced histoarchitectural and testicular disturbances that impaired testosterone levels and sperm quality. The CGG ethanol extract is reported to be non-toxic and could be a safe drug choice. Further studies, based on the current results, could lead to a new herbal candidate with antifertility properties.

\section{Authors' Contributions}

RW, SP, SHS, and JS contributed to the design and carried out the experiment, data analysis, and interpretation. Sample and histopathological analyses were performed by AL, TH, and MRAAS. RW and SP wrote the manuscript in consultation with all of the authors. All authors have revised and approved the final manuscript.

\section{Acknowledgments}

The authors gratefully acknowledge the University Grant for Basic Research, contract number: 171.61./ 
UN14.4.A/LT/2018, funded by the Indonesian Ministry of Research Technology and Higher Education for fiscal year 2019 .

\section{Competing Interests} interests.

The authors declare that they have no competing

\section{Publisher's Note}

Veterinary World remains neutral with regard to jurisdictional claims in published institutional affiliation.

\section{References}

1. Amory, J.K. (2019) Development of novel male contraceptives. Clin. Transl. Sci., 13(2): 1-10.

2. Joshi, R., Khadilkar, S. and Patel, M. (2015) Global trends in use of long-acting reversible and permanent methods of contraception: Seeking a balance. Int. J. Gynecol. Obstet., 131(1): S60-S63.

3. McKay, R. and Schunmann, C. (2015) Male and female sterilization. Obstet. Gynaecol. Reprod. Med., 25(5): 128-132.

4. Alphonse, A.A. and Mohan, V. (2017) Evaluation of antifertility potential of ethanolic extract of Bacolepis nervosa in male albino rats. Asian J. Pharm. Health. Sci., 7(2): 1675-1682.

5. Singh, K. and Gupta, R.S. (2016) Antifertility activity of $\beta$-sitosterol isolated from Barleria prionitis (L.) roots in male albino rats. Int. J. Pharm. Pharm. Sci., 8(5): 88-96.

6. Chandrakant, J., Shetty, A.N., Mety, S., Ali, M.L. and Mathad, P. (2018) In vivo assessment of antifertility potential of pteridophytic plants: Actiniopteris radiata (SW.) L. and Selaginella bryopteris (L.) Baker in swiss albino mice. Asian J. Pharm. Pharmacol., 5(1): 152-158.

7. Nayaka, H., Londonkar, R.L. and Umesh, M.K. (2014) Evaluation of potential antifertility activity of total flavonoids, isolated from Portulaca oleracea $\mathrm{L}$ on female albino rats. Int. J. Pharm.Tech. Res., 6(2): 783-793.

8. Hidayat, S. and Rachmadiyanto, A.N. (2017) Utilization of alang-alang (Imperata cylindrica (L.) Raeusch.) as traditional medicine in Indonesian archipelago. Proc Satreps Conf., 1: 82-89.

9. Subramaniam, S. and Sivasubramanian, A. (2015) Tradition to therapeutics : Sacrificial medicinal grasses Desmostachya bipinnata and Imperata cylindrica of India. Blacpma, 14(3): 156-170.

10. Umair, M., Altaf, M. and Abbasi, A.M. (2017) An ethnobotanical survey of indigenous medicinal plants in Hafizabad district, Punjab-Pakistan. PLoS One, 12(6): 1-22.

11. Ho, A., Kwok, Y., Wang, Y. and Ho, W.S. (2016) Cytotoxic and pro-oxidative effects of Imperata cylindrica aerial part ethyl acetate extract in colorectal cancer in vitro. Phytomedicine, 23(5): 558-565.

12. Lalthanpuii, P.B. and Lalchhandama, K. (2019) Chemical profiling, antibacterial and antiparasitic studies of Imperata cylindrica. J. Appl. Pharm. Sci., 9(12): 117-121.

13. Sulistyowati, E., Jan, R.L., Liou, S.F., Chen, Y.F., Wu, B.N., Hsu, J.H. and Yeh, J.L. (2019) Vasculoprotective effects of Centella asiatica, Justicia gendarussa and Imperata cylindrica decoction via the NOXs-ROS-NF-KB pathway in spontaneously hypertensive rats. J. Tradit. Complement. Med., 9(3): 1-10.

14. Lalthanpuii, P.B., Zarzokimi. and Lalchhandama, K. (2018) Imperata cylindrica: A noxious weed of pharmacological potentials. Adv. Eng. Res., 178: 173-177.

15. Al-shaikhli, R.J. and Al-Janabi, A.A. (2017) The cytogenetic effect of Euphorbia tirucalli stems methanolic extract on sperm head morphology in male albino mice. HOAJ Biol., 6(1): 1-6.
16. Daniyal, M. and Akram, M. (2015) Antifertility activity of medicinal plants. J. Chin. Med. Assoc., 78(7): 382-388.

17. Lubis, A., Widyastuti, R., Robianto, S., Priscilla, M. and Syamsunarno, M.R.A. (2018) Old mice epididymal sperm quality after short term gavage of cogon grass root ethanol extract old mice epididymal sperm quality after short term gavage of cogon grass root ethanol extract. Majalah Kedokt. Bandung, 50(2): 120-126.

18. Widyastuti,R.,Sudiman,J., Tyagita,H.,Syamsunarno,M.R.A. and Sumarsono, S.H. (2018) Oral administration of cogongrass (Imperata cylindrica L) root ethanol-extract causes mouse epididymal sperm abnormality. J. Vet., 19(3): 1-6.

19. Widyastuti, R., Boediono, A., Syamsunarno, M.R.A., Ghozali, M., Ritonga, M.A., Lubis, A., Robianto, S. and Sudiman, J. (2020) Effect of short-term gavage of ethanolic extract of cogongrass (Imperata cylindrica L.) root on the ovarian activity and estrus behaviour of female mice. Asian Pac. J. Reprod., 9(2): 70-76.

20. Semet,M.,Paci,M.,Saias-Magnan,J.,Metzler-Guillemain,C., Boissier, R., Lejeune, H. and Perrin, J. (2018) The impact of drugs on male fertility : A review. Andrology, 5(4): 640-663.

21. Johnsen, S.G. (1970) Testicular biopsy score count-a method for registration of spermatogenesis in human testes: Normal values and results in 335 hypogonadal males. Horm. Res. Paediatr., 1(1): 2-25.

22. R Core Team. (2016) R: A Language and Environment for Statistical Computing. R Foundation for Statistical Computing, Vienna, Austria. Available from: http:// www.R-project.org. Retrieved on 03-08-2019.

23. Cabeza, M., Sánchez-márquez, A., Garrido, M., Silva, A. and Bratoeff, E. (2016) Recent advances in drug design and drug discovery for androgen-dependent diseases. Curr. Med. Chem., 23(8): 792-815.

24. Song, B., Wang, F. and Wang, W. (2015) Effect of aqueous extract from Morinda officinalis F.C. how on microwave-induced hypothalamic-pituitary-testis axis impairment in male Sprague-Dawley rats. Evid. Based Complement. Alternat. Med., 2015: 360730.

25. Mozaffari, Z., Parivar, K., Roodbari, N.H. and Irani, S. (2015) Histopathological evaluation of the toxic effects of zinc oxide $(\mathrm{ZnO})$ nanoparticles on testicular tissue of NMRI adult mice. Adv. Stud. Biol.,7(6): 275-291.

26. Chapin, R.E., Ball, D.J., Radi, Z.A., Kumpf, S.W., KozaTaylor, P.H., Potter, D.M. and Mark, V.W. (2017) Effects of the janus kinase inhibitor, tofacitinib, on testicular leydig cell hyperplasia and adenoma in rats, and on prolactin signaling in cultured primary rat leydig cells. Toxicol. Sci., 155(1): 148-156.

27. Yoshida, S. (2016) From cyst to tubule: Innovations in vertebrate spermatogenesis. Wiley Interdiscip. Rev. Dev. Biol., 5(1): 119-131.

28. de Boer, P., de Vries, M. and Ramos, L. (2015) A mutation study of sperm head shape and motility in the mouse: Lessons for the clinic. Andrology, 3(2): 174-202.

29. Oduwole, O.O., Peltoketo, H. and Huhtaniemi, I.T. (2018) Role of follicle-stimulating hormone in spermatogenesis. Front. Endocrinol., 9: 1-11.

30. Shpakov, A., Rhyzhov, J.R., Bakhtyukov, A. and Derkach, K. (2018) The regulation of the male hypothalamic-pituitary-gonadal axis and testosterone production by adipokines. In: Estrada, M., editors. Advances in Testosterone Action. Intech Open Access Publisher, Rijeka, Croatia. p25-57.

31. Vidal, J.D. and Whitney, K.M. (2014) Morphologic manifestation of testicular and epididymal toxicity. Spermatogenesis, 4(2): e979099.

32. Zhou, W., de Iuliis, G.N., Dun, M.D. and Nixon, B. (2018) Characteristics of the epididymal luminal environment responsible for sperm maturation and storage. Front. Endocrinol., 9: 1-13.

33. Gervasi, M.G. and Visconti, P.E. (2017) Molecular changes and signaling events occurring in spermatozoa during 
epididymal maturation. Andrology, 5(2): 204-218.

34. Oridupa, O.A., Samuel, B.B. and Amolegbe, A.A. (2018) Sperm morphology and characteristics in male rats treated with leaf extract Combretum sordidum. Afr. J. Biomed. Res., 21(1): 51-55.

35. Wang, R., Song, B. and Shao, L. (2018) Potential adverse effects of nanoparticles on the reproductive system. Int. J. Nanomed., 13: 8487-8506.

36. Dewal, S., Sharma, R. and Gupta, R.S. (2018) A review on antifertility activity of plants of Chambal riverine. Asian $J$. Pharm. Clin. Res., 11(8): 8-14.

37. Sharma, D.K. and Mali, P.C. (2016) Inhibition of spermatogenesis with the treatment of $50 \%$ methanolic extract of Maytenus emarginata leaves in albino rats. Int. J. Pharm. Sci. Res., 7(8): 3379-3387.
38. Sreedhar, N.B., Dangi, N.B., Sapkota, H.P., Wagle, N., Nagarjuna, S., Sankaranand, R. and Kumari, B.A. (2016) Phytochemical screening and evaluation of anti-fertility activity of Dactyloctenium aegyptium in male albino rats. Asian Pac. J. Reprod., 5(1): 51-57.

39. Shalaweh, S.M., Erasmus, N., Weitz, F. and Henkel, R.R. (2014) Effect of Cissampelos capensis rhizome extract on human spermatozoa in vitro. Andrologia, 47(3): 1-10.

40. Mali, P.C., Singh, A.R., Verma, M.K., Chahar, M.K. and Dobhal, M.P. (2015) Contraceptive effects of withanolide-a in adult male albino rats. Adv. Pharmacol. Toxicol., 16(1): 31-44.

41. Kalita, A., Ahmed, K. and Kalita, J.C. (2016) Effects of methanolic leaf extract of Catharanthus roseus (L.) G. Don on certain reproductive parameters of male albino mice. NBU J. Anim. Sci., 10: 31-38.

$* * * * * * * *$ 